\title{
Judo teaching models in Portugal: For the knowledge and comprehension of the sporting training process in this discipline
}

\author{
Rui VELOSO *1, Manuel BOTELHO ${ }^{1}$, \& Ágata ARANHA ${ }^{2}$ \\ ${ }^{1}$ Faculty of Sports of the Oporto University (FADEUP) (Portugal) \\ 2 Trás-os-Montes e Alto Douro University (UTAD) (Portugal)
}

\section{5th IMACSSS World Scientific Congress Abstracts, Rio Maior (Portugal), October 6-8 \\ Section: Coaching, training and health issues in MA\&CS \\ Type: Poster communication}

\section{Introduction}

The aim of this study is to explore the Portuguese judo coaches' understanding on some fundamental aspects of the global judoka's sports education process. It is also an aim to present a summarized education model, based on the coaches' understanding, and to focus on the aspects to be strengthened in the various age groups.

From a general point of view, Feliu (2005) suggests four main goals to be achieved in sports for children and young people concerning the physical, sporting, psychological and social levels: to improve their physical and athletic condition through sporting and physical exercise; to learn or improve the adequate technical and tactical skills for each sport; to develop self-confidence and to learn to compete with fair play; to promote opportunities to socialize with friends and make new acquaintances. From the judo's specific point of view, Villamón and Molina (1999) introduced some interesting aspects regarding the sporting initiation, such as: the importance of the contextual determinants (teacher/coach and practice place), its orientations (educational, sporting or recreational), the issues related to the early specialization and the steps of the sporting initiation process. The authors also approach two theoretical models of judo initiation (technical and alternative), as well as the subject of competition during the initiation process: its features, educational component, as well as a competition proposal adapted to the sporting initiation.

The Long-Term Athlete Development Model, applied to judo is also concerned with the judoka's path (competitive and recreational aspects), as well as his participation throughout life (Judo Canada 2006). As far as sports practice is concerned, Amaro (2005) points out that it should lay on a multilateral training of the motor skills and sporting abilities. Also in this context, Marques (2005) stresses that, in the sports training of the younger, athletes these are not supposed to perform the most advanced practices but should be prepared to be able to do that in the future. It is also useful to stress the importance of discovery promoting strategies, which facilitate the confrontation with their own decision-taking in the search of new solutions, contributing thus for the development of autonomy (Mesquita 2004).

\section{Methodology}

The qualitative methodology was used, by means of a semi-structured interview as well as a small questionnaire. The interviews were conducted by sixteen Portuguese coaches from five different regions of the country (the North, the Center, Lisbon, the South and the Azores), and were recorded for ulterior answer handling through content analysis. 


\section{Results}

A category based analysis was made of all the answers to the various questions of the interview. From this analysis various categories were formed. We highlight the ones mentioned by a bigger number of coaches: Attitudes and values, Judo on the ground, Sports training, Transition between standing/on the ground, Technical factor, Parents' support, Transfer, Motivation, Motivation/Recreational teaching, Discovery and creativity, Dirigism, refereeing and training, Competition (formal/adapted) and Promotion of the personal style, among others.

\section{Discussion and conclusion}

In general, the results obtained in our study are in accordance with what can be read in the literature. Based on this results some conclusions were drawn: judo teaching builds on the attitudes and values transmission; parents play a crucial role as dedicated and respectful agents of the coaches' decisions, showing the latter an exemplary behavior to set the example; the teaching of recreational features is an important source of motivation for the practice; the lack of collaborators and the rather heterogeneous classes are some of the problems felt by the coaches; the correct teaching of falls and techniques, as well as the stress given to the ground fight (with beginners), and a suitable competitive regulation improve safety in the practice; good technical basis, a wide variety of learning, as well as the use of problem situations are important aspects in the context of the judoka's sports education; it is generally understood that the work with the transition between standing/on the ground judo should be started early; after the techniques learning process, athletes should be given space for the development of their own personal style; judo teaching should, progressively, prepare the athletes for the future competitive demands, respecting, however, their stage of development; contacts with judokas from other clubs are fundamental for the athletes' evolution; coaches have not always justified conveniently their options regarding the work of the motor abilities and skills, as well as the logic behind the choice of the teaching situations.

\section{References}

Amaro, J. 2005. Programa de Preparación del Deportista - Deporte "Judo". Retrieved from www.inder.co.cu

Feliu, J. (2005). El Papel de los Padres en la Promoción del FairPlay en Deportistas Jóvenes. In: Conferência Internacional - O Desporto, a Educação e os Valores: por uma ética nas atividades físicas e desportivas, 79-90. LIsboa: COFAC - Cooperativa de Informação e Animação Cultural e

Judo Canada. (2006). Long-Term Athlete Development - Judo. Retrieved from http://www.judocanada.org/long-term-athlete-development-model

Marques, A. (2005). Do valor educativo da competição desportiva. Razões e equívocos. In: $A$ Educação Pelo Desporto - Perspectivas Europeias (pp. 114-121). Lisboa: Instituto do Desporto de Portugal.

Mesquita, I. (2004). Tarefa prioritária do treinador: ensinar a aprender. In: Seminário Internacional sobre Treino de Jovens. Lisboa: Instituto do Desporto de Portugal.

Villamón, M., \& Molina, J.P. (1999). La iniciación deportiva en el judo. In M. Villamón (Ed.), Introdución al judo (pp. 145-165). Barcelona: Hispano Europea.

Key words: Judo; content analysis; sports education; training; teaching model; combat sports. 